\title{
Sistem Informasi Donor Darah Pada Unit Tranfusi Darah Palang Merah Indonesia Kota Dumai Berbasis Website
}

\author{
Khairatunnisa ${ }^{1}$, Febrina Sari ${ }^{2}$ \\ 1,2 Program Studi Teknik Informatika, Sekolah Tinggi Teknologi Dumai \\ Jl. Utama Karya Bukit Batrem II \\ Email: khairatunnisa321@gmail.com
}

\begin{abstract}
ABSTRAK
Selama proses pendistribusian stok darah kepada masyarakat maupun rumah sakit, pihak pasien harus mencari stok darah lansung ke UTD PMI Dumai. Dalam sehari permintaan darah bisa mencapai 10 hingga 15 kantong darah perharinya. Jika stok darah habis, keluarga pasien harus mencari pendonor sendiri untuk mendonorkan darahnya, hal ini menyulitkan bagi keluarga pasien dalam mencari pendonor pengganti. Kurangnya kesadaran masyarakat Kota Dumai dalam pentingnya mendonorkan darah membuat UTD PMI Dumai mengalami kesulitan mengelola stok darah yang ada. Mengingat volume permintaan stok darah setiap harinya yang lebih banyak dibanding pemasukkan stok darah pada UTD PMI. Untuk mengatasi kekosongan stok darah, maka UTD PMI Dumai meminta penggantian darah kepada pihak pasien. Berdasarkan dari masalah tersebut, peneliti melakukan penelitian di UTD PMI Dumai dengan membangun sistem informasi donor darah berbasis website yang dapat mempermudah masyarakat untuk mengaskses stok darah dan data pendonor.
\end{abstract}

Kata kunci: Sistem, Informasi, Website, Donor Darah

\begin{abstract}
During the process of distributing blood stocks to the community and hospitals, the patient must look for blood stocks directly to UTD PMI Dumai. In a day the demand for blood can reach 10 to 15 bags of blood per day. If the blood stock runs out, the patient's family must find their own donor to donate their blood, this makes it difficult for the patient's family to find a replacement donor. The lack of public awareness of Dumai City in the importance of donating blood makes UTD PMI Dumai have difficulty managing the existing blood stock. Given the volume of demand for blood stock every day which is more than the input of blood stock at UTD PMI. To overcome the vacancy of blood stock, UTD PMI Dumai asked for blood replacement from the patient. Based on these problems, researchers conducted research at UTD PMI Dumai by building a website-based blood donor information system that can make it easier for the public to access blood stocks and donor data.
\end{abstract}

Keywords: System, Information, Website, Blood Donors 


\section{Pendahuluan}

Teknologi Informasi berkembang dengan sangat pesat di berbagai bidang kehidupan, menuntut manusia untuk dapat mengikuti perkembangannya dengan menerapkan system pada berbagai kegiatan sehari-hari (Yanti, 2018) terutama pada kegiatan administrasi dan pengolahan data di Institusi dan Organisasi. Palang merah indonesia merupakan sebuah organisasi netral dan independen di Indonesia yang aktivitasnya di bidang sosial kemanusiaan (Daradjatun, 2008). PMI dibentuk dengan tugas pokok membantu pemerintah Indonesia di bidang sosial kemanusiaan. Tugas-tugas kemanusiaan itu meliputi kesiapsiagaan bantuan dan penanggulangan bencana, pelatihan pertolongan pertama untuk sukarelawan, pelayanan kesehatan dan kesejahteraan masyarakat, serta pelayanan transfusi darah, dengan adanya penerapan teknologi maka pengolahan data akan lebih efektif (Sidik, 2018).

Pelayanan tranfusi darah merupakan upaya pelayanan kesehatan yang terdiri dari serangkaian kegiatan mulai dari pengerahan dan pelestarian donor, pengambilan, pengamanan, pengolahan, penyimpanan darah dan tindakan medis pemberian darah kepada pasien untuk tujuan penyembuhan penyakit dan pemulihan kesehatan.

Unit Tranfusi Darah (UTD) PMI kota Dumai merupakan instansi yang melayani pendonoran darah, serta menyediakan stok darah bagi masyarakat di kota Dumai. Sebagai instansi yang menyediakan pendonoran dan tranfusi darah, pihak UTD PMI Dumai harus sigap dalam melayani baik dalam keadaan mendesak maupun keadaan waktu libur. UTD PMI Dumai selalu siaga dalam pemberian pelayanan kesehatan kepada warga maupun rumah sakit yang membutuhkan stok darah.

Selama proses pendistribusian stok darah kepada masyarakat maupun rumah sakit, pihak pasien harus mencari stok darah lansung ke UTD PMI Dumai. Dalam sehari permintaan darah bisa mencapai 10 hingga 15 kantong darah perharinya. Jika stok darah habis, keluarga pasien harus mencari pendonor sendiri untuk mendonorkan darahnya, hal ini menyulitkan bagi keluarga pasien dalam mencari pendonor pengganti.

Kurangnya kesadaran masyarakat Kota Dumai dalam pentingnya mendonorkan darah (Wulandari, 2015) membuat UTD PMI Dumai mengalami kesulitan dalam mengelola stok darah yang ada. Mengingat volume permintaan stok darah setiap harinya yang lebih banyak dibanding pemasukkan stok darah pada UTD PMI. Untuk mengatasi kekosongan stok darah, maka UTD PMI Dumai meminta penggantian darah kepada pihak pasien, oleh karena itu perlu adanya Sistem Informasi Donor Darah pada Unit Tranfusi Darah (UTD) PMI Kota Dumai Berbasis Website. Penggunaan website telah lama digunakan sebagai solusi dalam penyampaian informasi seperti yang telah dilakukan oleh (Handayani, 2017).

Penelitian ini merujuk pada beberapa penelitian terdahulu yang membahas permasalah serupa yakni (Harsiwi, 2018) tentang pentingnya kegiatan donor darah Terhadap kesehatan. (Sonita, 2019) membuat aplikasi Seleksi bagi calon pendonor darah, sedangkan (Shobar, 2016) membangun system pengingat bagi pendonor dorah menggunakan teknologi Location Base service.

\section{Metode Penelitian}

Metode pengembangan system ini adalah menggunakan model SDLC (Software Development Life Cycle) air terjun atau waterfall (Sari, 2018). Waterfall sering di sebut juga model sekuensial linier atau alur hidup klasik. Model air terjun menyediakan pendekatan alur hidup perangkat lunak secara sekuensial atau 
terurut di mulai dari analisis, desain, implementasi, dan pengujian (Shalahuddin \& A.S, 2011).

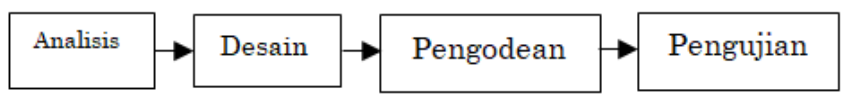

Gambar 1. Waterfall

\section{Hasil dan Pembahasan}

Hasil merupakan tingkat keberhasilan yang didapat dari sistem yang telah di bangun melalui berbagai tahap. Hasil dari sistem ini dapat mempermudah masyarakat dalam mencari informasi tentang pendonor sukarelawan sebagai pengganti kantong darah yang telah diambil pasien dan sistem ini dapat mengatasi kesulitan dalam mencari informasi tentang stok darah.

\section{Rancangan Sistem}

Tahap ini merupakan tahap pembahasan dari sistem yang akan dibangun. Rancangan sistem berarti menggambarkan tampilan dan cara kerja dari sistem secara global, yang terdiri dati beberapa tahapan sebagai berikut :

\section{Use Case Diagram}

Permodelan dengan use case diagram untuk menunjukkan interaksi antara use case diagram dengan actor.

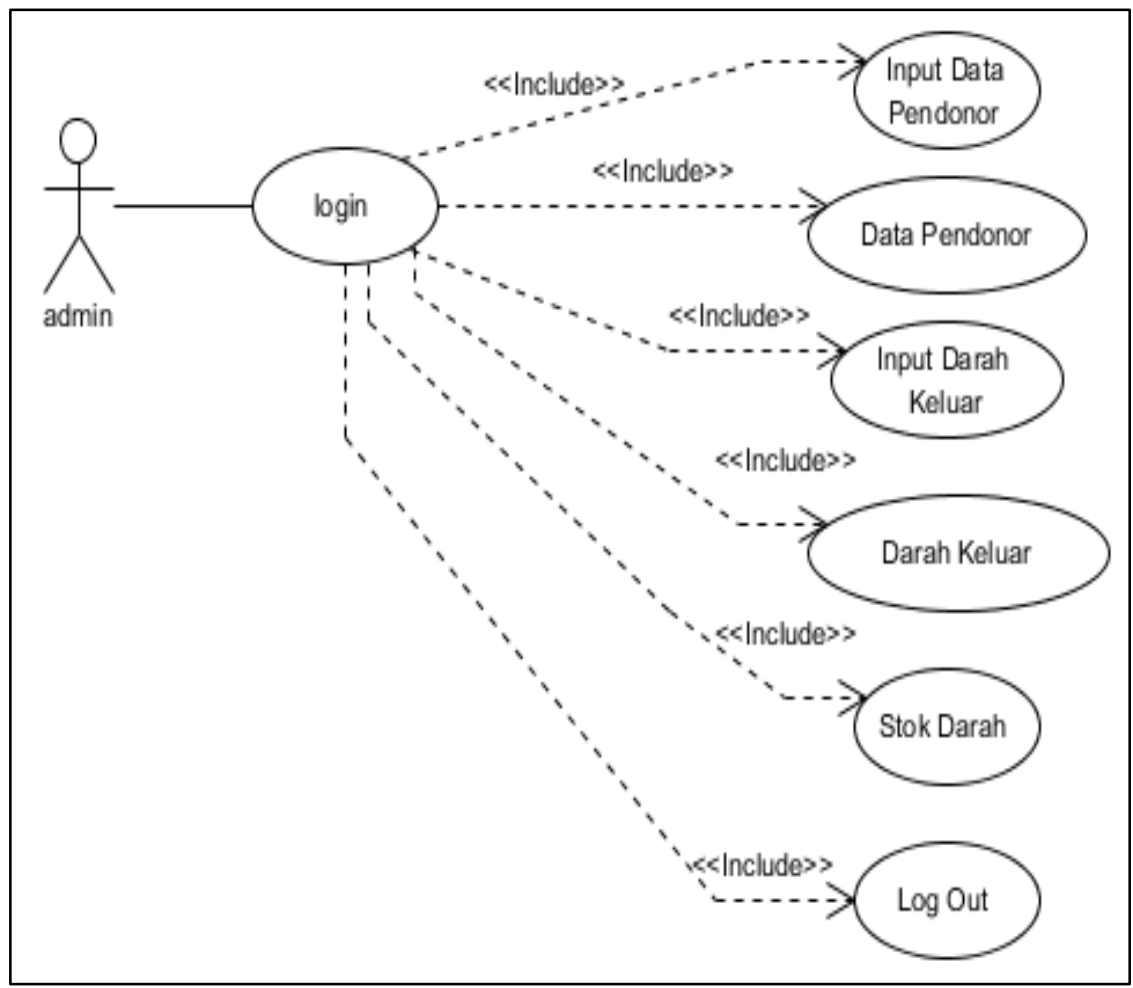


Unitek : Jurnal Universal Teknologi

Vol. 14 No.1 Januari-Juni 2021

e-ISSN : 2580-2582, p-ISSN: 2089-3957

Gambar 2. Use Case Diagram

\section{Class Diagram}

Class Diagram adalah sebuah spesifikasi yang jika diinstansiasi akan menghasilkan sebuah obyek dan merupakan inti dari pengembangan dan desain berorientasi obyek. Sebuah class diagram digunakan untuk menunjukkan keberadaan dari kelas dan hubungannya di dalam pandangan logic dari sebuah sistem, hal ini dapat dilihat pada gambar berikut.

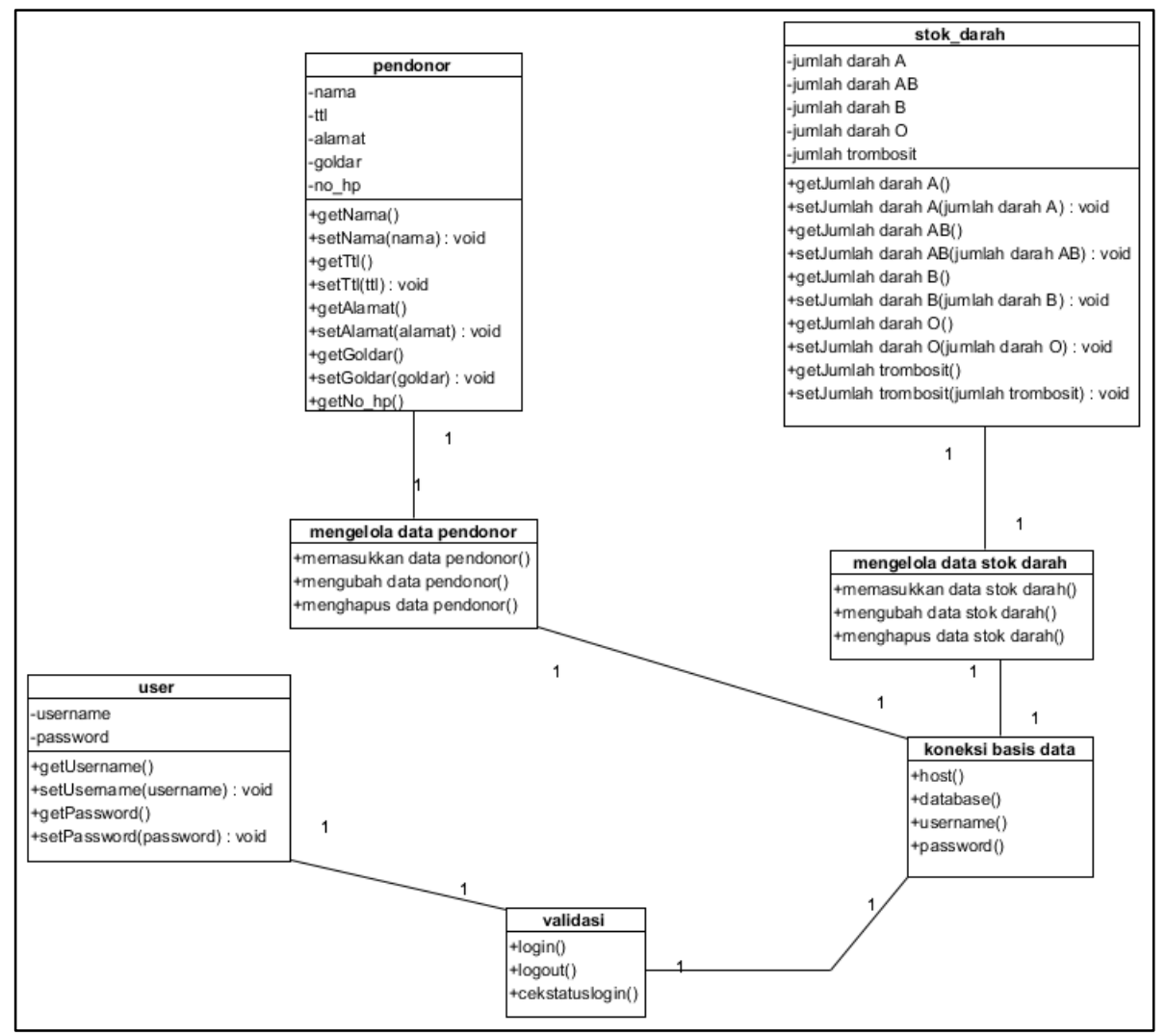

Gambar 3. Class Diagram

\section{Implementasi Sistem}

Tahap implementasi sistem ini dilaksanakan guna melihat kinerja system apakah dapat berjalan dengan baik dan setiap menu yang ada berfungsi sebagaimana mestinya. Sistem ini didesain dengan beberapa halaman untuk lebih memudahkan user mendapatkan informasi yang dibutuhkan.

1. Halaman Login

Halaman login admin sebagai akses masuk kedalam Sistem Informasi Donor Darah Berbasis Website dengan memasukkan username dan password yang benar. 
Unitek : Jurnal Universal Teknologi

Vol. 14 No.1 Januari-Juni 2021

e-ISSN : 2580-2582, p-ISSN: 2089-3957

2. Halaman Utama

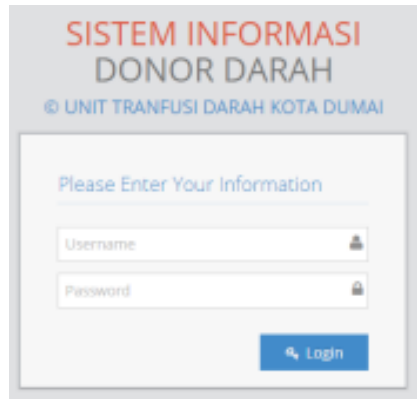

Gambar 4. Halaman Login

Halaman utama akan tampil jika proses login berhasil, halam utama ini merupakan halaman awal dari system yang mengediakan informasi seputar visi dan misi UTD PMI Dumai, berikut tampilan halaman utama.

\section{- Sistem Informasi Donor Darah Berbasis Web}

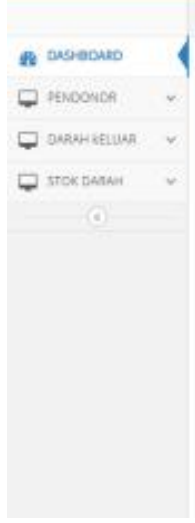

1

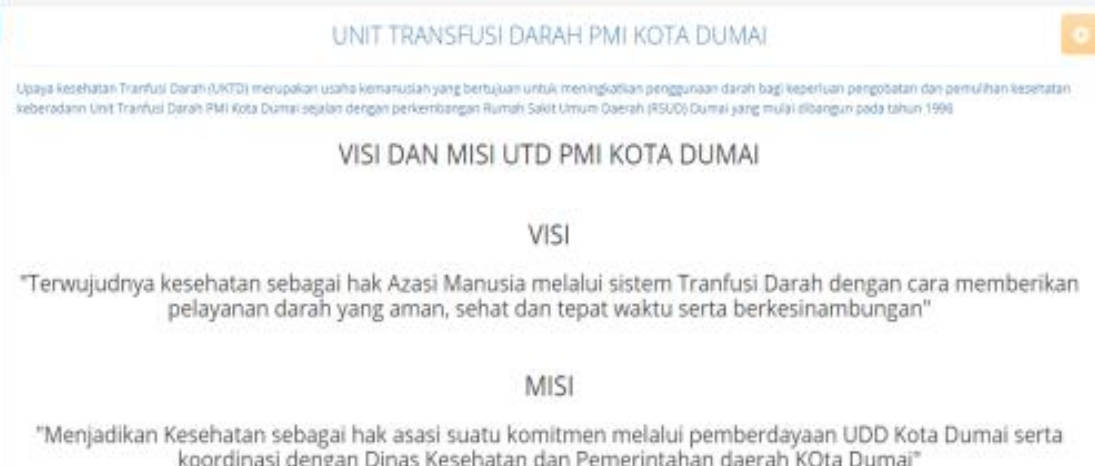

\section{Gambar 5. Halaman Utama}

3. Halaman Input Pendonor

Tampilan berikutnya adalah Halaman input pendonor, halaman ini merupakan form yang berguna untuk memasukkan data para pendonor darah yang dapat dilihat pada gambar berikut 
Unitek : Jurnal Universal Teknologi

Vol. 14 No.1 Januari-Juni 2021

e-ISSN : 2580-2582, p-ISSN: 2089-3957

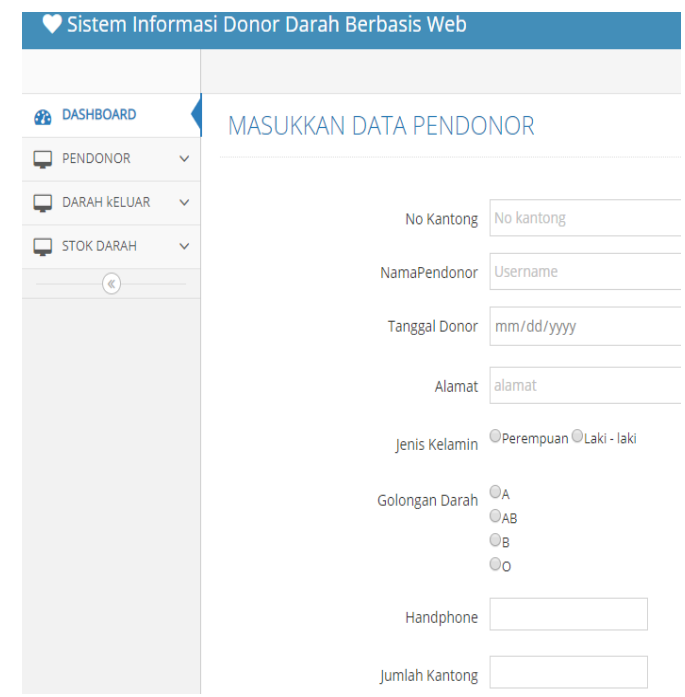

Gambar 6. Halaman Input Pendonor

4. Halaman Tampil Data Pendonor

Halaman ini menyediakan tabel berrisikan data para pendonor darah yang sudah di inputkan ke dalam system informasi donor, berikut gambar halaman tampilan data pendonor

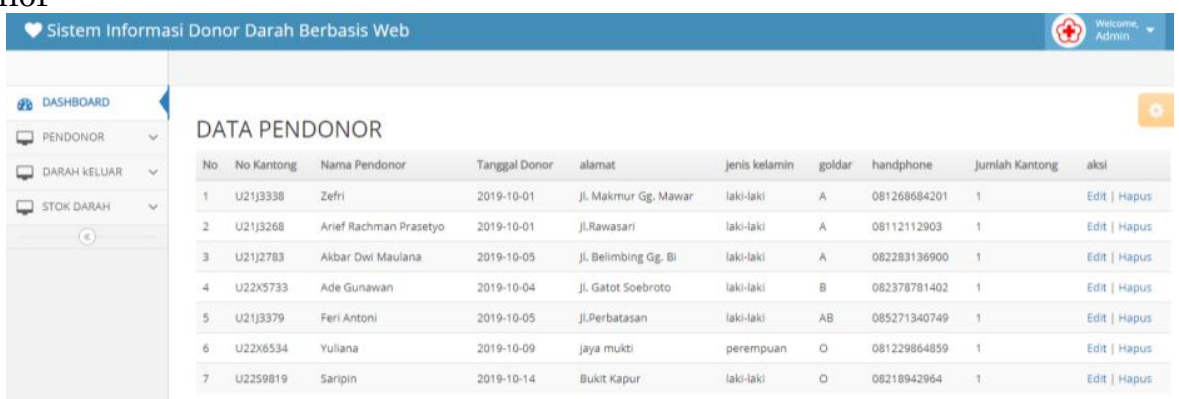

Gambar 7. Halaman Data Pendonor.

5. Halaman Input Darah Keluar

Halaman input Darah Keluar merupakan form yang disediakan pada sistem guna untuk memasukkan data darah yang di ambil oleh masyarakat atau pihak rumah sakit, data ini akan mempengaruhi data stok darah oleh karenanya data darah keluar sangat penting untuk diinputkan, berikut tampilannya. 
Unitek : Jurnal Universal Teknologi

Vol. 14 No.1 Januari-Juni 2021

e-ISSN : 2580-2582, p-ISSN: 2089-3957

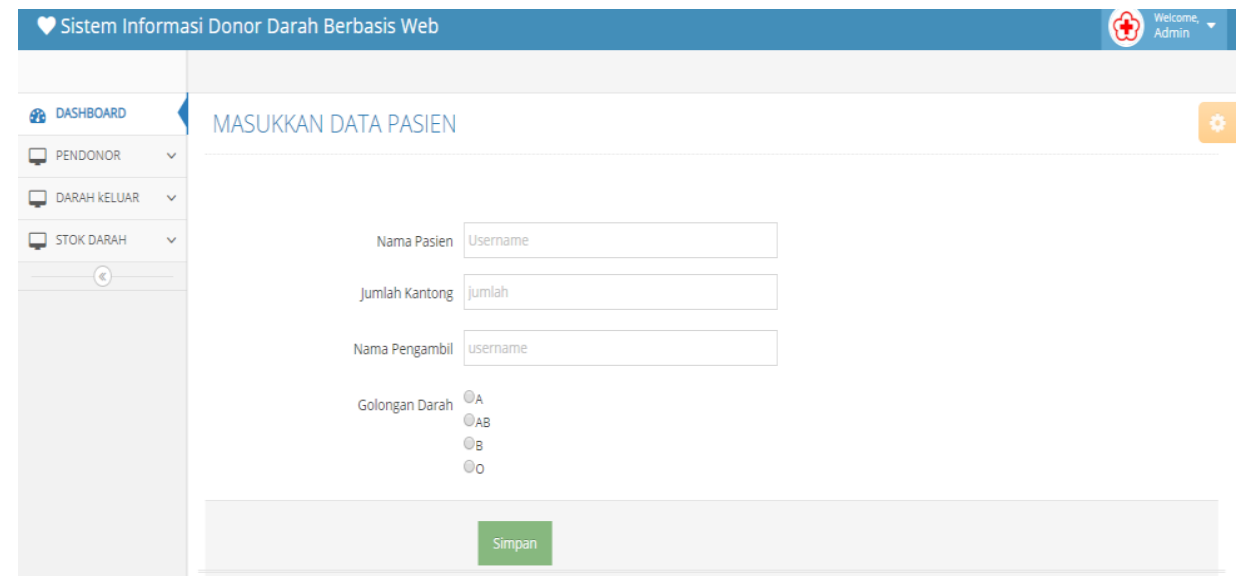

Gambar 8. Halaman Input Darah Keluar

6. Halaman Tampil Data Darah Keluar

Halaman tampil data darah keluar ini merupakan hasil dari input data darah keluar, data akan tersimpan dalam bentuk table yang dapat dilihat pada gambar berikut ini.

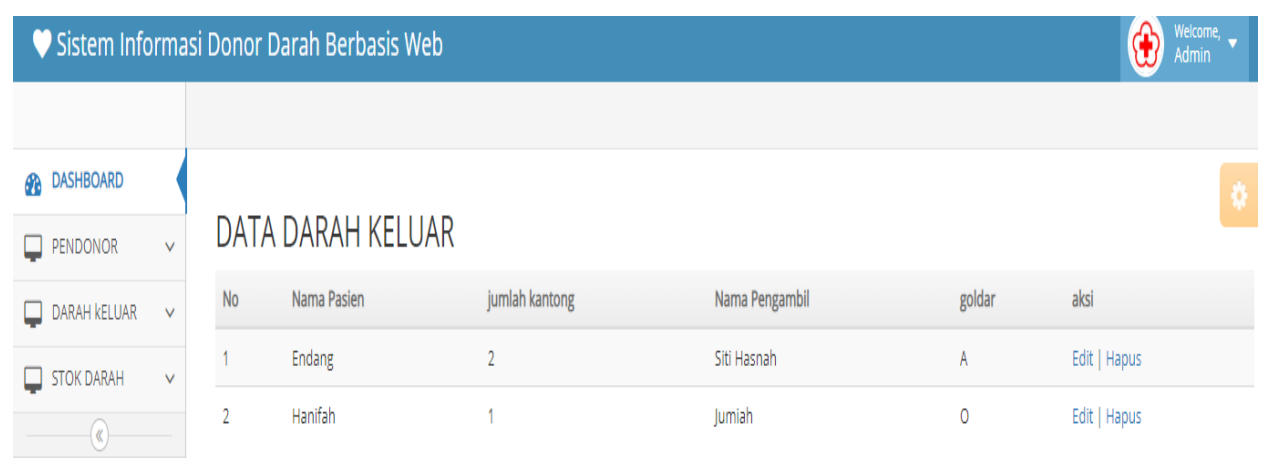

Gambar 9. Halaman tampil darah keluar

7. Halaman Tampil Stok Darah

Halaman Tampil stok darah keluar menyediakan tabel untuk melihat data stok darah yang tersedia saat ini untuk semua jenis darah, form ini juga berguna untuk memberikan informasi kepada PMI agar segera memenuhi stok darah yang sudah kosong. Berikut tampilannya

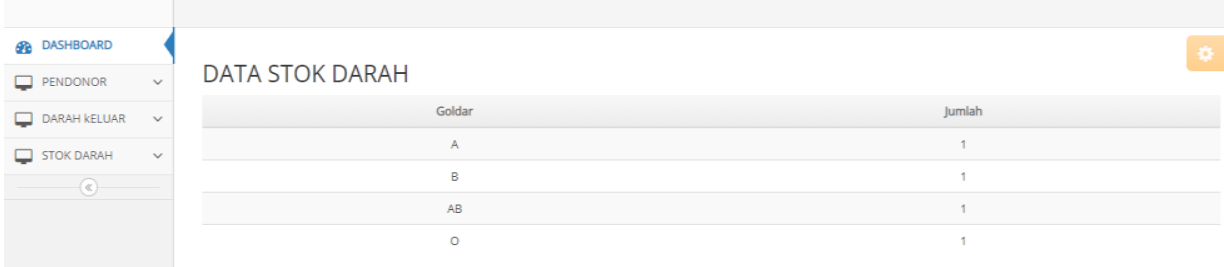

Gambar 10. Halaman Stok Darah 


\section{Simpulan}

Sistem Informasi Donor Darah Berbasis Web Pada UTD PMI Kota Dumai dapat mempermudah petugas PMI dalam mengelolah data pendonor, data stok darah dan system ini dapat memberikan informasi terkait dengan ketersediaan stok darah dengan lebih cepat dan akurat. Sistem Informasi Donor Darah ini juga memberikan manfaat yang sangat besar bagi masyarakat dalam mencari informasi tentang pendonor sukarelawan jika stok darah yang dibutuhkan tidak tersedia di PMI,

\section{Daftar Pustaka}

A.S, Rosa., \& Shalahuddin, M.(2011). Rekayasa Perangkat Lunak. Bandung: Modula.

Daradjatun (2008). Pedoman Pelayanan Transfusi Darah. Jakarta: UTD PMI Pusat.

Harsiwi, U. B., \& Arini, L. D. D., (2018). Tinjauan Kegiatan Donor Darah Terhadap Kesehatan Di PMI Karanganyar, Jawa Tengah Tahun 2018. Jurnal INFOKES, Vol.8 No.1. ISSN : 2086-2628.

Handayani, T., Sari, F., \& Setyawan, A., (2017). Rancang Bangun Sistem Informasi Hotel dan Penginapan di Kota dumai Berbasis Web. Seminar Nasional Teknologi Informasi Komunikasi dan Industri (SNTIKI) 2017. Pekanbaru Riau. Hal. 57-63.

Sari, F., Nurhadi, N., Herianto, H., Hadiansa, A., \& Suranti, D., (2018). Model Early Warning System Based Android. IOSR Journal of Engineering (IOSR-JEN) Volume.8. Nomor 10, Hal. 29-37.

Shobar, I. A., \& Albarda. (2016). Sistem Reminder Donor Darah dengan Memanfaatkan Teknologi Location Based Service. Jurnal Edukasi dan Penelitian Informatika (JEPIN) Vol.2, No.2. ISSN 2460-0741.

Sholiq. (2010). Analisis \& Perancangan Berorientasi Obyek. Yogyakarta: Graha Ilmu.

Sidik, A., Tekat, E., Waluyo, B., \& Susilawati, S. (2018). Perancangan Sistem Informasi Laporan Persediaan Barang Jadi PT Duta Prima Plasindo. 8(1).

Sinita, A., \& Kundari, R., (2019) Aplikasi Seleksi Calon Pendonor Darah Menggunakan Algoritme C4.5. Jurnal Pseudocode. Volume.VI Nomor.2. ISSN 2355-5920, e-ISSN 2655-1845.

Wulandari, S., Widjanarko, B., \& Kusyogo. 2015. Analisis Niat Donor Darah Sukarela (DDS) untuk Konseling Menerima Hasil Test di Unit Donor Darah (UDD) PMI Kabupaten Semarang. Jurnal Promosi Kesehatan Indonesia. Vol. 10 No.2. Agustus 2015.

Yanti, E., Sari, F., \& Satria, D., (2018). Sistem Informasi Penyaluran Bahan Bakar Minyak (BBM) dan Transporter di PT Putri Kharisma. Repository Sekolah Tinggi Teknologi Dumai. 